\title{
A rapid and simple one-pot procedure for the synthesis of $3 \beta$-acetoxy-5 $\alpha$-hydroxy-6-oxo steroids
}

\author{
Anielka Rosado-Abón, Margarita Romero-Ávila, Martin A. and Iglesias-Arteaga* \\ Facultad de Química.Universidad Nacional Autónoma de México, Ciudad Universitaria \\ E-mail: martin.iglesias@servidor.unam.mx
}

\begin{abstract}
A fast one-pot procedure for the synthesis of 5a-hydroxy-6-oxo steroids is described. Epoxidation of $3 \beta$-hydoxy- $\Delta^{5}$ steroids followed by oxidative cleavage of the resulting epoxide with aqueous $\mathrm{CrO}_{3}$ lead to the desired compounds without affection of labile side chains.
\end{abstract}

Keywords: Epoxides, oxidative cleavage, $5 \alpha$-hydroxy-6-oxo steroids, one-pot

\section{Introduction}

Steroids bearing a 3 $\beta, 5 \alpha$-dihydroxy-6-oxo moiety have served as starting materials for the synthesis of different bioactive compounds including plant growth regulators, ${ }^{1,2}$ ecdysteroids antagonists, ${ }^{3} 5 \alpha$-reductase inhibitors ${ }^{4,5}$ or antagonists of the androgen receptor, ${ }^{6}$ among others. In general, the limited number of protocols for the preparation of such compounds start from derivatives of $3 \beta$-hydroxy- $\Delta^{5}$-steroids and involve the oxidation of 5,6-diols (iii), ${ }^{1,3}$ or the oxidative cleavage of $5 \xi, 6$-epoxides by treatment with Jones reagent ${ }^{2}$ or $\mathrm{CrO}_{3}$ (iv) ${ }^{5}$ (Scheme 1).

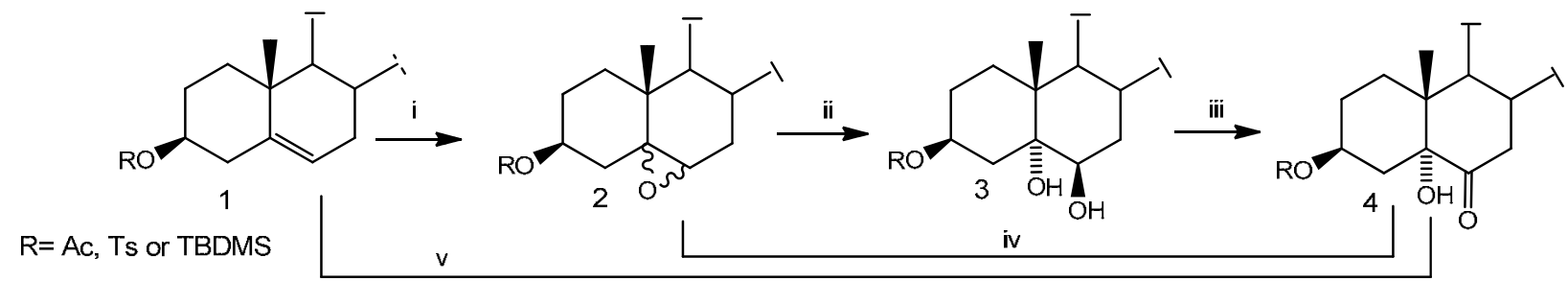

i) $\mathrm{MCPBA} / \mathrm{CH}_{2} \mathrm{Cl}_{2}$ or $\mathrm{KMnO}_{4} / \mathrm{Fe}_{2}\left(\mathrm{SO}_{4}\right)_{3}, \mathrm{t}-\mathrm{BuOH} / \mathrm{CH}_{2} \mathrm{Cl}_{2} / \mathrm{H}_{2} \mathrm{O}$; ii) $\mathrm{H}_{2} \mathrm{O} / \mathrm{HClO}_{4}$ /acetone; iii) Jones reagent or PCC; iv) Jones reagent or $\mathrm{CrO}_{3}$ v) $\mathrm{KMnO}_{4} / \mathrm{Fe}\left(\mathrm{ClO}_{4}\right)_{3} \cdot \mathrm{nH}_{2} \mathrm{O}$

\section{Scheme 1}

Recently, Salvador and coworkers reported that treatment of different $3 \beta$-acetoxy- $\Delta^{5}$-steroids (androstane, pregnanes and cholestane series) with $\mathrm{KMnO}_{4} / \mathrm{Fe}\left(\mathrm{ClO}_{4}\right)_{3}$ in heterogeneous media 
for 8 to 24 hours (v), produced the corresponding $3 \beta$-acetoxy- $5 \alpha$-hydroxy-6-oxo steroids in 70 to $81 \%$ yields $^{7}$ in an elegant approach in which the risks associated to the explosive nature of $\mathrm{Fe}\left(\mathrm{ClO}_{4}\right)_{3}$ may constitute a general limitation in the preparation of large amounts of the desired ketols (Scheme 1).

There are some reports that indicate that steroids bearing labile side chain may be affected by the acid conditions that predominate in the hydrolytic and oxidative cleavage of epoxides or in Jones oxidation of diols. Barton reported that treatment of steroid sapogenins with $\mathrm{CrO}_{3}$ in acetic acid yielded the corresponding sapogenoic acid as a result of the oxidative opening of the spirostanic side chain (equation 1). ${ }^{8}$ On the other hand, we described that treatment of furostanols with the $\mathrm{KMnO}_{4} / \mathrm{Fe}_{2}\left(\mathrm{SO}_{4}\right)_{3}$ cleaved the E-ring to afford 16,22-diones, (equation 2). ${ }^{9}$

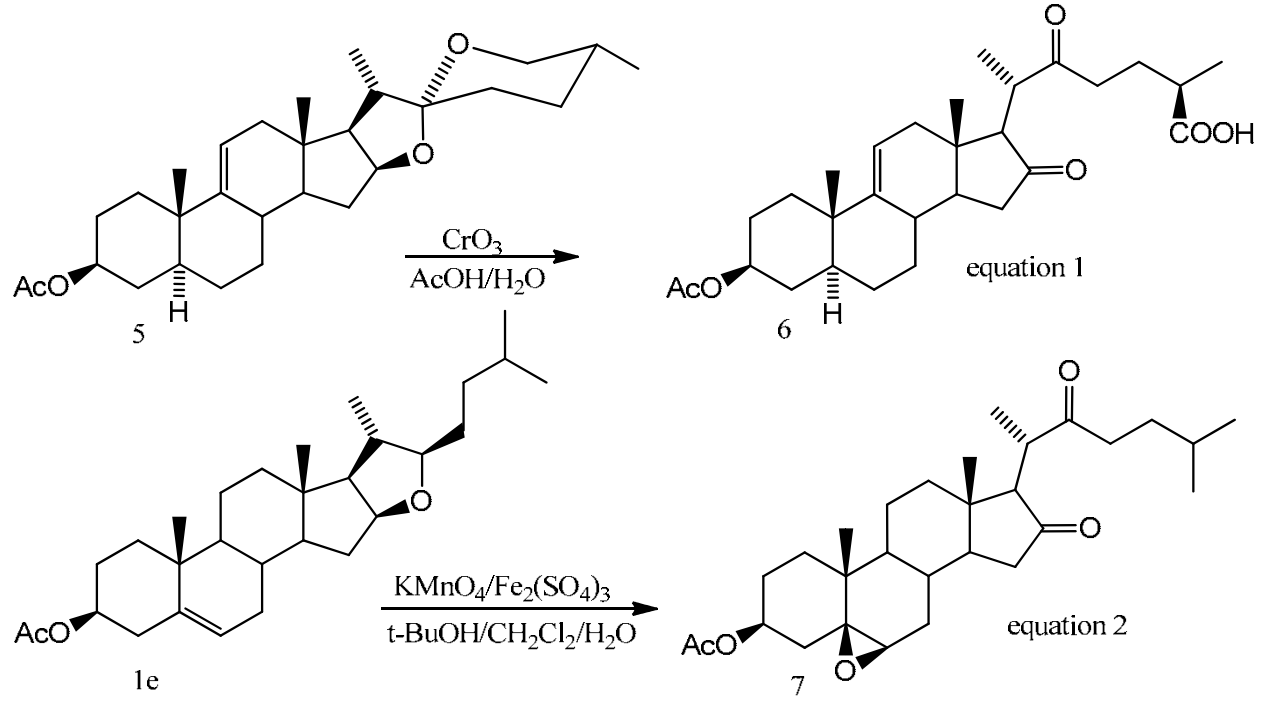

As a part of our project on the synthesis of bioactive compounds, we have directed our attention to a series of $3 \beta$-acetoxy-5 $\alpha$-hydroxy-6-oxo steroids bearing different oxygenated side chains as starting materials in the preparation of potentially bioactive compounds. Consequently, we decided to set up optimized experimental conditions that avoid the above-mentioned limitations that hinder the preparation of $3 \beta$-acetoxy- $5 \alpha$-hydroxy-6-oxo steroids bearing acid labile side chains. Herein we report on a simple one-pot procedure that allows the rapid preparation of such compounds in 1 to $10 \mathrm{mmol}$ amounts without isolation of the intermediate epoxides 2 or diols $3 .{ }^{10}$ In addition, a carefully assignment of NMR signals of the obtained compounds is provided.

\section{Results and Discussion}

As expected, treatment of the $3 \beta$-acetoxy- $\Delta^{5}$-steroids 1a-f with $m$-CPBA in $\mathrm{CH}_{2} \mathrm{Cl}_{2}$ produced mixtures of the corresponding $5 \alpha$-and $5 \beta$-epoxides. While oxidative cleavage of the epoxides 
derived from compounds 1a-d, could be carried out by treatment with Jones reagent, similar treatment of those derived from 1e-f produced mixtures of the desired ketol and variable amounts of products due to reaction of the side chain. The avoidance of strongly acidic conditions by substitution of Jones oxidant by a solution of $\mathrm{CrO}_{3}$ in water prevents the reaction of the acid sensitive furostanic E-ring and spirostanic side chain, affording the desired ketols in high yield and purity. In those conditions, addition of acetone to the $\mathrm{CH}_{2} \mathrm{Cl}_{2}$ solution resulting from the epoxidation reaction, followed by cooling and treatment with $\mathrm{CrO}_{3}$ produces the conversion of the epoxides into the corresponding ketol in 77-95\% yields, in a fast and convenient one-pot procedure that does not affect the studied labile side chains (see Scheme 2 and Table 1).

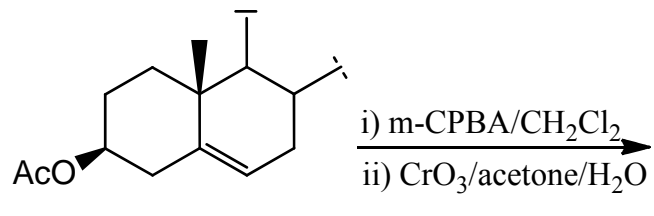

1a-f

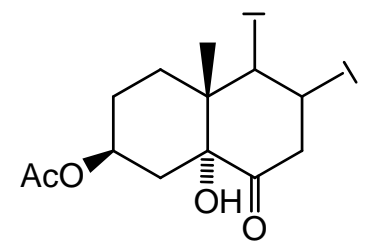

4a-f

Scheme 2

\section{Experimental Section}

General. Reactions were monitored by TLC on ALUGRAM ${ }^{\circledR}$ SIL G/UV254 plates from MACHEREY-NAGEL. Chromatographic plates were sprayed with a $1 \%$ solution of vanillin in $50 \% \mathrm{HClO}_{4}$ and heated until color developed. NMR spectra were recorded in $\mathrm{CDCl}_{3}$ solutions in Varian INOVA 400 and $300 \mathrm{MHz}$ spectrometers using the solvent signal $7.26 \mathrm{ppm}$ for ${ }^{1} \mathrm{H}$ and $77.00 \mathrm{ppm}$ for ${ }^{13} \mathrm{C}$ as reference. NMR signals were assigned with the aid of DEPT and combination of ${ }^{1} \mathrm{H}-{ }^{1} \mathrm{H}$ COSY and Heteronuclear Single Quantum Correlation (HSQC). All 2D NMR spectra were recorded by using the standard pulse sequences and parameters recommended by the manufacturer. Melting points were measured on a Melt-Temp II apparatus and are uncorrected.

\section{General procedure for ketol formation}

$m$-CPBA $(0.968 \mathrm{~g}, 5.61 \mathrm{mmol})$ was added to a solution of the $3 \beta$-acetoxy- $\Delta^{5}$-steroid $(4 \mathrm{mmol})$ in $\mathrm{CH}_{2} \mathrm{Cl}_{2}(20 \mathrm{~mL})$ and the mixture was stirred until the starting material disappeared (1 to $1.5 \mathrm{~h}$, TLC). Acetone $(50 \mathrm{~mL})$ was added and the mixture was cooled to $0^{\circ} \mathrm{C}$ in an ice bath before addition of a solution of $\mathrm{CrO}_{3}(1.43 \mathrm{~g}, 14.3 \mathrm{mmol})$ in water $(4.3 \mathrm{~mL})$ The ice bath was removed, the mixture was stirred at room temperature for $20 \mathrm{~min}$. and cooled to $0^{\circ} \mathrm{C}$ in the ice bath prior to dropwise addition of a solution of $\mathrm{CrO}_{3}(0.71 \mathrm{~g}, 7.1 \mathrm{mmol})$ in water $(2.2 \mathrm{~mL})$. The ice bath was removed and the mixture stirred for $50 \mathrm{~min}$, before addition of water $(50 \mathrm{~mL})$ and extraction with ethyl acetate $(2 \times 50 \mathrm{~mL})$. The organic layer was washed with water $(9 \times 50 \mathrm{~mL}), 10 \% \mathrm{NaHCO}_{3}$ 
solution $(5 \times 50 \mathrm{~mL})$, water $(2 \times 50 \mathrm{~mL})$ and saturated $\mathrm{NaCl}$ solution $(1 \times 50 \mathrm{~mL})$, dried and evaporated to afford the desired ketol (see Table 1 for yields).

Table 1. Formation of ketols

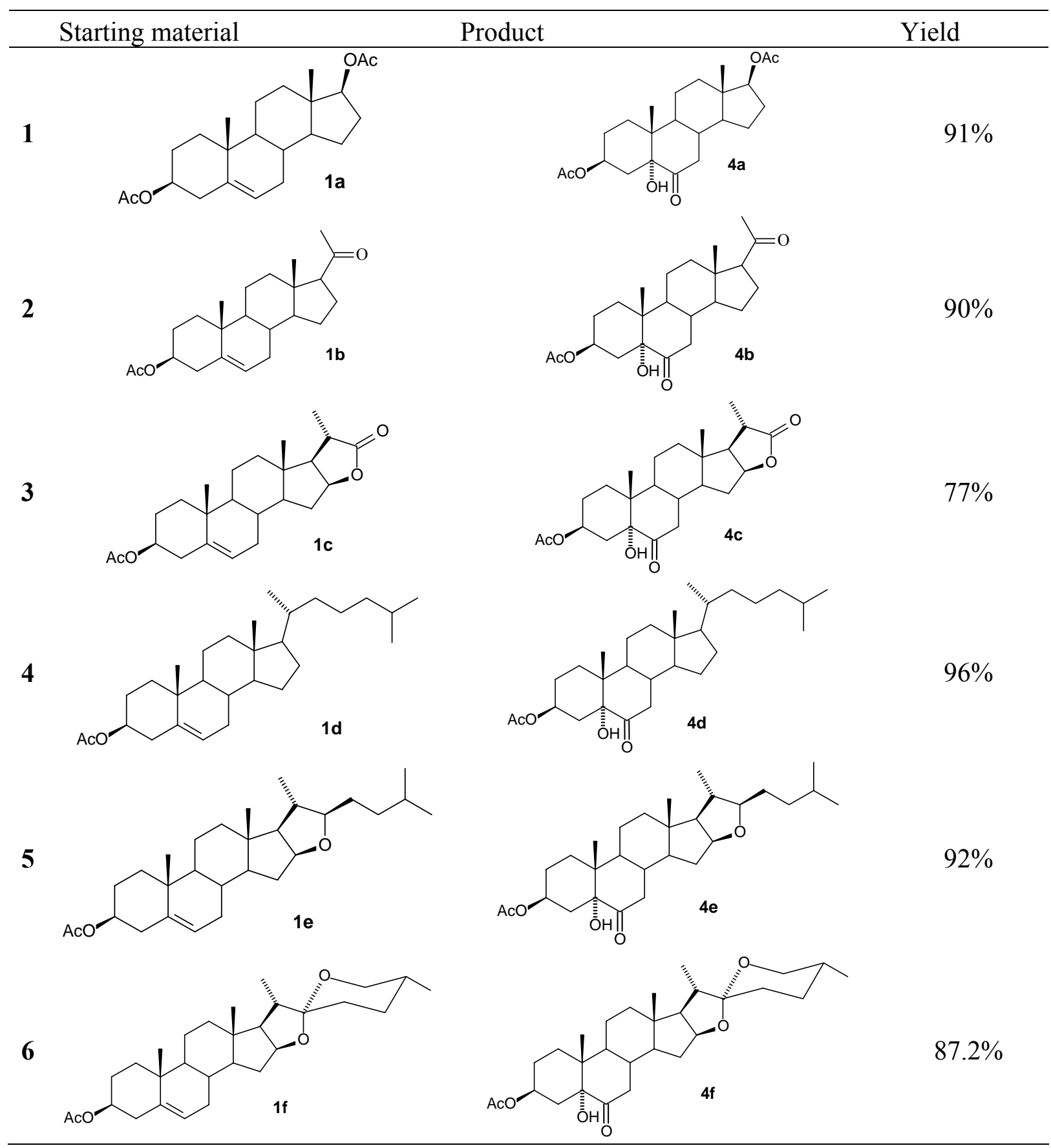

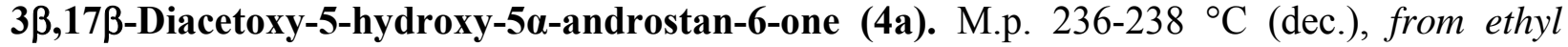
acetate. Lit. $236-237.5^{\circ} \mathrm{C} .{ }^{11}{ }^{1} \mathrm{H}$ NMR ( $\delta$ ppm): 5.03 (m, $1 \mathrm{H}, \mathrm{H}-3$ ); $4.62(\mathrm{dd}, J=9.1,7.8 \mathrm{~Hz}, 1 \mathrm{H}$, $\mathrm{H}-17$ ); 2.76 (dd, $J=13.9,11.4 \mathrm{~Hz}, 1 \mathrm{H}, \mathrm{H}-7$ ax.); 2.03 (s, 3H, $\left.\mathrm{CH}_{3} \mathrm{COO}-17\right) ; 2.00$ (s, 3H, 
$\left.\mathrm{CH}_{3} \mathrm{COO}-3\right) ; 0.82$ (s, 3H, H-19); 0.77 (s, 3H, H-18). ${ }^{13} \mathrm{C}$ NMR $(\delta \mathrm{ppm}): 29.50 \mathrm{C}-1 ; 26.20 \mathrm{C}-2$; 70.73 C-3; 32.21 C-4; 80.06 C-5; 212.16 C-6; 41.12 C-7; 37.02 C-8; 44.17 C-9; 42.47 C-10; 20.82 C-11; 36.50 C-12; 43.12 C-13; 50.64 C-14; 23.22 C-15; 27.37 C-16; 82.37 C-17; 12.01 C$18 ; 13.84 \mathrm{C}-19 ; 21.09$ and $21.32 \underline{\mathrm{CH}}_{3} \mathrm{COO}-3$ and $\underline{\mathrm{CH}}_{3} \mathrm{COO}-17 ; 171.12,171.15 \mathrm{CH}_{3} \underline{\mathrm{COO}}-3$ and C $\mathrm{H}_{3} \mathrm{COO}-17$.

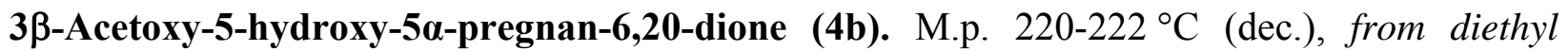
ether, Lit. $223-224.5^{\circ} \mathrm{C} .{ }^{12}{ }^{1} \mathrm{H}$ NMR $(\delta$ ppm): 5.02 (m, 1H, H-3); 2.78 (dd, $J=12.6,12.6 \mathrm{~Hz}, \mathrm{H}-7$ ax.); 2.54 (dd, $J=8.9,8.9 \mathrm{~Hz}, \mathrm{H}-17) ; 2.10$ (s, 3H, $\left.\mathrm{CH}_{3} \mathrm{COO}-3\right) ; 0.58$ (s, 3H, H-18); 0.79 (s, 3H, $\mathrm{H}-21) ; 1.99$ (s, 3H, H-21). NMR ${ }^{13} \mathrm{C}(\delta \mathrm{ppm}): 29.52 \mathrm{C}-1 ; 26.21 \mathrm{C}-2 ; 70.63 \mathrm{C}-3 ; 32.27 \mathrm{C}-4 ; 80.09$ C-5; 211.94 C-6; 41.46 C-7; 37.09 C-8; 44.49 C-9; 42.39 C-10; 21.28 C-11; 38.57 C-12; 44.11 C-13; 56.34 C-14; 24.06 C-15; 22.72 C-16; 63.40 C-17; 13.34 C-18; 13.85 C-19; 209.22 C-20; $31.41 \mathrm{C}-21 ; 21.33 \underline{\mathrm{CH}}_{3} \mathrm{COO}-3 ; 171.06 \mathrm{CH}_{3} \underline{\mathrm{COO}}-3$.

$3 \beta$-Acetoxy-5,16 $\beta$-dihydroxy-6-oxo-5 $\alpha$-dinorcholanic acid $22 \rightarrow 16$ lactone (4c). Identical to our previous report. ${ }^{13}$ M.p. $282.2-280.6{ }^{\circ} \mathrm{C}$ from acetone. ${ }^{1} \mathrm{H}$ NMR $(\delta \mathrm{ppm}): 0.71(\mathrm{~s}, 3 \mathrm{H}, \mathrm{H}-18)$; 0.80 (s, 3H, H-19); 1.30 (d, $J=7.6 \mathrm{~Hz}, 3 \mathrm{H}, \mathrm{H}-21) ; 1.98$ (s, 3H, $\left.\mathrm{CH}_{3} \mathrm{COO}-3\right) ; 2.08$ (dd, $J=4.5$ $\mathrm{Hz}, 12.3 \mathrm{~Hz}, 1 \mathrm{H}, \mathrm{H}-7$ equatorial); 2.21 (m, 1H, H-15); 2.56 (m, 1H, H-20); 2.78 (dd, J = 12.3, $12.3 \mathrm{~Hz}, 1 \mathrm{H}, \mathrm{H}-7$ axial); 4.93 (m, 1H, H-16); 5.01 (m, H-3). ${ }^{13} \mathrm{C}$ NMR ( $\left.\delta, \mathrm{ppm}\right): 26.2 \mathrm{C}-1 ; 29.5$ C-2; 70.6 C-3; 32.2 C-4; 79.9 C-5; 211.4 C-6; 41.5 C-7; 36.4 C-8; 44.2 C-9; 42.4 C-10; 20.6 C11; 37.9 C-12; 42.2 C-13; 54.3 C-14; 32.7 C-15; 82.3 C-16; 58.8 C-17; 13.7 C-18; 13.9 C-19; 36.0 C-20; 17.9 C-21; 181.0 C-22; $171.1 \mathrm{CH}_{3} \underline{\mathrm{COO}}-3 ; 21.3 \mathrm{CH}_{3} \mathrm{COO}-3$.

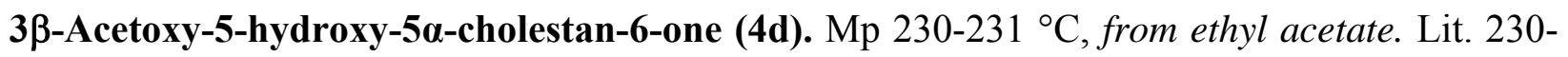
$231{ }^{\circ} \mathrm{C} .{ }^{14}{ }^{1} \mathrm{H}$ NMR $(\delta \mathrm{ppm}): 5.05-4.94(\mathrm{~m}, 1 \mathrm{H}, \mathrm{H}-3$ ); 2.78 (dd, $J=12.6,12.6 \mathrm{~Hz}, 1 \mathrm{H}, \mathrm{H}-7$ ax. ); $2.01\left(\mathrm{~s}, 3 \mathrm{H}, \mathrm{CH}_{3} \mathrm{COO}-3\right.$ ); $0.91(\mathrm{~d}, J=6.3 \mathrm{~Hz}, 3 \mathrm{H}, \mathrm{H}-21)$; 0.87 and $0.85(\mathrm{~d}, J=6.6 \mathrm{~Hz}, 3 \mathrm{H}$ each, H-26 and H-27 ); 0.81 (s, 3H, H-19); 0.64 (s, 3H, H-18). ${ }^{13} \mathrm{C}$ NMR ( $\delta$ ppm): $32.03 \mathrm{C}-1$, 28.17 C-2, 71.52 C-3, 28.17 C-4, 79.82 C-5, 213.77 C-6, 41.80 C-7, 37.52 C-8, 44.25 C-9, 42.61 C-10, 21.46 C-11, 39.57 C-12, 43.22 C-13, 56.38 C-14, 26.41 C-15, 29.64 C-16, 56.24 C-17, 12.08 C-18, 13.91 C-19, 35.84 C-20, 18.70 C-21, 36.21 C-22, 24.03 C-23, 29.68 C-24, 28.09 C25, $22.87 \mathrm{C}-26,23.96 \mathrm{C}-27,171.82 \mathrm{CH}_{3} \underline{\mathrm{COO}}-3,22.61 \mathrm{CH}_{3} \mathrm{COO}-3$.

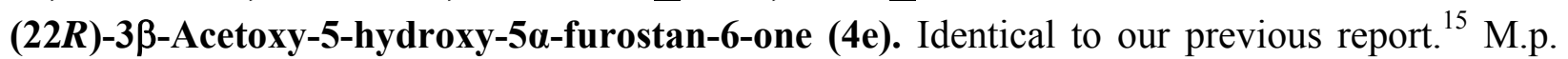
184-186 ${ }^{\circ} \mathrm{C}$, from ethyl acetate/hexane. ${ }^{1} \mathrm{H}$ NMR ( $\left.\delta \mathrm{ppm}\right): 5.15-4.88$ (m, 1H, H-3); 4.33-4.23 (m, 1H, H-16 ); 3.33-3.24 (m, 1H, H-22); 2.75 (dd, J = 11.6, 11.6 Hz, 1H, H 7ax.); 1.98 (s, 3H, $\mathrm{CH}_{3} \mathrm{COO}-3$ ); 0.98 (d, $\left.J=6.41 \mathrm{~Hz}, 3 \mathrm{H}, \mathrm{H}-21\right) ; 0.86$ (d, $J=6.37 \mathrm{~Hz}, 6 \mathrm{H}, \mathrm{H}-26$ and H-27); 0.81 (s, $3 \mathrm{H}, \mathrm{H}-18) ; 0.76$ (s, 3H, H-19). ${ }^{13} \mathrm{C}$ NMR ( $\left.\delta \mathrm{ppm}\right): 29.48 \mathrm{C}-1 ; 26.20 \mathrm{C}-2 ; 70.63 \mathrm{C}-3 ; 32.29 \mathrm{C}-4$; 80.10 C-5; 212.00 C-6; 41.69 C-7; 36.88 C-8; 44.26 C-9; 42.41 C-10; 20.96 C-11; 39.19 C-12; 41.44 C-13; 56.46 C-14; 31.90 C-15; 82.76 C-16; 65.12 C-17; 16.46 C-18; 13.92. C-19; 37.85 C20; 18.97 C-21; 90.42 C-22; 28.20 C-23; 31.32 C-24; 35.77 C-25; 22.52 C-26; 22.45 C-27; 171.06; $\mathrm{CH}_{3} \underline{\mathrm{COO}}-3 ; 21.33 \underline{\mathrm{CH}}_{3} \mathrm{COO}-3$.

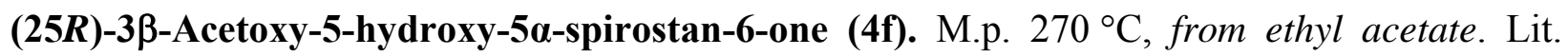
268-269 ${ }^{\circ} \mathrm{C} .{ }^{16}{ }^{1} \mathrm{H}$ NMR $(\delta \mathrm{ppm}): 5.02$ (m, 3H, H-3); 4.41 (m, 1H, H-16); 3.47 (ddd, $J=10.8,4.5$, $1.7 \mathrm{~Hz}, 1 \mathrm{H}, \mathrm{H}-26$ eq.); 3.36 (dd, $J=10.9,10.9$ Hz, H-26 ax.); 2.77 (dd, $J=12,12.9 \mathrm{~Hz}, 1 \mathrm{H}, \mathrm{H}-$ 
7); 2.01 (s, 3H, $\mathrm{CH}_{3} \mathrm{COO}-3$ ); 0.97 (d, $J=6.8 \mathrm{~Hz}, 3 \mathrm{H}, \mathrm{H}-21$ ); 0.83 (s, 3H, H-19); 0.79 (d, $J=6.4$ $\mathrm{Hz}, 3 \mathrm{H}, \mathrm{H}-27) ; 0.76$ (s, 3H, H-18). ${ }^{13} \mathrm{C}$ NMR ( $\left.\delta \mathrm{ppm}\right): 29.48 \mathrm{C}-1 ; 26.24 \mathrm{C}-2 ; 70.71 \mathrm{C}-3 ; 32.30 \mathrm{C}-$ 4; 80.10 C-5; 212.05 C-6; 41.77 C-7; 36.74 C-8; 44.28 C-9; 42.46 C-10; 21.17 C-11; 39.54 C12; 41.05 C-13; 56.03 C-14; 31.51 C-15; 80.48 C-16; 62.02 C-17; 16.36 C-18; 13.93 C-19; 41.59 C-20; 14.40 C-21; 109.26 C-22; 31.32 C-23; 28.74 C-24; 30.23 C-25; 66.83 C-26; 17.07 C-27; $171.14 \mathrm{CH}_{3} \underline{\mathrm{COO}}-3 ; 21.32 \underline{\mathrm{CH}_{3} \mathrm{COO}-3 .}$

\section{Acknowledgements}

We thank Dirección General de Asuntos del Personal Académico (DGAPA-UNAM) for financial support via project IN-204008 and CONACyT (Mexico) for the scholarship granted to A.R-A. We are indebted to Nuria Esturau-Escofet for registering all NMR spectra.

\section{References and Notes}

1. Ramírez, J. A.; Teme-Centurión, O. M.; Gros, E. G.; Galagovsky, L. R. Steroids 2000, 65, 329.

2. Brosa, C.; Soca, L.; Terricabras E.; Ferrer, J. C.; Alsina, A. Tetrahedron 1998, 54, 12337.

3. Rivera, D. G.; León F.; Coll, F.; Davison G. P. Steroids 2006, 71, 1.

4. Bratoeff, E.; Cabeza, M.; Pérez-Ornelas, V.; Recillas, S.; Heuze, I. J. Steroid Biochem. 2008, 111, 275.

5. Perez-Ornelas, V.; Cabeza, M.; Bratoeff, E.; Heuze I.; Sánchez, M.; Ramírez, E.; NaranjoRodriguez, E. Steroids 2005, 70, 217.

6. Cabeza, M.; Bratoeff, E.; Ramírez, E.; Heuze, I.; Recillas, S.; Berrios, H.; Cruz, A.; Cabrera, O.; Pérez, V. Steroids 2008, 73, 838.

7. Salvador, J. A. R.; Moreira, V. M.; Hanson, J. R. Carvalho, R. A. Steroids 2006, 71, 266.

8. Barton, D. H. R.; Kulkarni, Y. D.; Sammes, P.G.; J. Chem. Soc. (C) 1971, 1149.

9. Rosado-Abon, A.; Romero-Avila, M.; Iglesias-Arteaga M. A. Arkivoc 2008, (xiv), 274.

10. Copies of the $1 \mathrm{H}$ and $13 \mathrm{C}$ NMR spectra can be found in the supplementary information file. All spectra were processed using MestReC or MestReNova (http://mestrelab.com).

11. Knof, L. Ann Chem 1961, Bd 647, 53.

12. Rubin, M. B.; Brown, A. P. J. Org. Chem. 1968, 33, 2794.

13. Mola-Garate, J. L.; Suárez-García, L.; Pérez-Martinez, C. S.; Iglesias-Arteaga, M. A.; CollHerrera, D.; Coll-Manchado, F. Synth. Commun. 2003, 33, 1203.

14. Fieser, L. F. J. Am. Chem. Soc. 1953, 75, 4386.

15. Romero-Avila, M.; de Dios-Bravo, G.; Mendez-Stivalet, J. M.; Rodríguez-Sotres, R.; Iglesias-Arteaga, M. A. Steroids 2007, 72, 955.

16. Wei-Shan, C.; Ta-Chumg, H.; Huang-Minlon Нuaxue Xuebao 1962, 28, 394. 